\title{
Editorial
}

\section{A plea for innovation with brands}

Having worked for 12 years at a company (Craton Lodge \& Knight) whose sole product has been the facilitation and provision of innovation and change, you may think that my plea for innovation is an obviously chosen one.

I would beg to differ, on the basis that many of the issues to do with a different debate - the crisis facing brands - can be linked to the lack of innovation and new products in many marketplaces.

Increasingly, senior management has begun to appreciate the gravity of the situation. Of the major fmcg multinationals, Unilever is perhaps the most vociferous proponent of innovation but there is a deafening silence from so many of the brand-owning companies on this issue.

So, if one of the most successful brand owners of the 1980s and 1990s has overtly espoused innovation, why have not all the others? I believe that this is simply because innovation has both enemies and barriers to overcome. First, there is an axiomatic conflict between the world as it is and the world as it might be. Those advocating change, disruption of the old patterns and the adoption of the new, must face up to and defeat the conservatism of the existing company hierarchies. The conservatives, as we shall call them, have some powerful arguments on their side.

Their conservatism is underpinned by the correct apprehension that few new products succeed. They will cite the comforting rollcall of brands launched in the 1930s, 1940s and 1950s which are still brand leaders today. Among such brands are great names like Dettol, Heinz Baked Beans, Milk of Magnesia, Hoover vacuum cleaners and Ajax. The
Conservatives enjoyed a great decade in the 1980s as innovation dwindled and corporate profits were swollen by the unsubtle strategy of 'inflation plus' price increases. With inflation averaging over 5 per cent throughout the 'eighties, the consumer did not notice the extra few percentage points of margin added each year. This cosy arrangement came to an abrupt end with the advent of a recession combined with a forecast for the medium term of a low inflation economy. Manufacturers and service providers are faced by a stark need to innovate and to sell more volume and, in turn, to increase profits. The Conservatives, however, have not been routed yet.

The hierarchies and systems that companies adopt nearly always favour the competent manager of what already exists rather than the risk-taker or proponent of change. In most companies the advocates of change have to be extraordinarily brave and thickskinned to see their projects endorsed by senior managers.

As if this were not enough, the 1980s have seen the apotheosis of the retailer. Power has slipped inexorably from the manufacturer to the retailer.

The change in this balance of power has had direct and damaging consequences for innovation in many marketplaces. In particular, regular innovation in packaged goods is limited to a few highly-branded sectors like detergents, pet food, soft drinks and premium ice cream. There are many sectors where manufacturers have simply given up the fight.

Certainly, for the present, manufacturers should understand that they need to work in 
context with the retailer but, in the long term, they must redress the balance of power through innovation and channel management to survive as branded manufacturers. Those who control their own distribution have done markedly better than those who do not, across a broad spectrum from Apple Computers to BP or Shell forecourts to the Royal Bank of Scotland's Direct Line Insurance operation. What should branded manufacturers learn from this?

If innovation is important, what principles should underpin its operation and management within a business? Experience suggests that the following five success factors are among the most critical:

- clear business goals for innovation;

- effective project sponsorship;

- the deployment of experienced innovators;

- senior management support and a profound belief in the intrinsic quality;

- value of the product being developed.

If these success factors are cross-referenced with the innovation performance of companies like Virgin Music, Sony, Microsoft, McDonald's and First Direct, there is a clear correlation.

Although the systems supporting and generating innovation naturally resist institutionalisation, few companies steer a steadycourse on their commitment to new products. Once innovation is forsaken as an intrinsic component of business strategy by a company, it is only a matter of time before that company is unable to compete effectively and it will be taken over or fail.

As a member of the Editorial Board of The Journal of Brand Management, I would certainly welcome further papers on innovation with brands, both from academic sources and those in manufacturing and service industries, because it is a critical longterm component of commercial success.

Finally, for anyone unconvinced by the need for change and innovation, I would urge them to read the European Commission's white paper on Growth Competitiveness and Employment.

Richard Zambuni Editorial Board

\section{Reference}

(1) Commission of The European Communities White Paper (1993)

'Growth, Competitiveness and Employment - The Challenges and Way Forward into the 21st Century'. 